\title{
Anthelmintic acetogenin from Annona squamosa L. Seeds
}

\author{
MARTA M.C. SOUZA ${ }^{1}$, CLAUdiA M.L. BEVILAQUA ${ }^{1}$, SELENE M. MORAIS ${ }^{2}$, CÍCERO T.C. COSTA ${ }^{1}$, \\ ANA R.A. SILVA ${ }^{2}$ and RAIMUNDO BRAZ-FILHO ${ }^{3}$ \\ ${ }^{1}$ Laboratório de Doenças Parasitárias, Universidade Estadual do Ceará, Av. Parajana 1700, 60740-000 Fortaleza, CE, Brasil \\ ${ }^{2}$ Curso de Química, Universidade Estadual do Ceará, Av. Parajana 1700, 60740-000 Fortaleza, CE, Brasil \\ ${ }^{3}$ Setor de Química de Produtos Naturais, Universidade Estadual do Norte Fluminense, 28013-600 Campos, RJ, Brasil
}

Manuscript received on September 12, 2006; accepted for publication on November 12, 2007;

contributed by RAIMUNDO BRAZ FILHO*

\begin{abstract}
Annona squamosa seeds extracts showed anthelmintic activity against Haemonchus contortus, the main nematode of sheep and goat in Northeastern Brazil. A compound 1 was isolated from ethyl acetate extract and inhibited the egg hatching of $H$. contortus at $25 \mathrm{mg} \mathrm{ml}^{-1}$. The structure of $\mathbf{1}$ was determined as a $\mathrm{C}_{37}$ trihydroxy adjacent bistetrahydrofuran acetogenin based on spectroscopic analysis.
\end{abstract}

Key words: Haemonchus contortus, nematodes, Annonacea, phytotherapy.

\section{INTRODUCTION}

In Northeastern Brazil, gastrointestinal parasitism of sheep and goats is one of the leading causes of mortality, producing high economic losses (Pinheiro et al. 2000). Among gastrointestinal nematodes, Haemonchus contortus is the most frequent and pathogenic, being responsible for the high mortality rate in young animals during the rainy season (Menezes et al. 1992, Arosemena et al. 1999). Trying to reduce these losses, synthetic anthelmintics are routinely used, often indiscriminately, causing reduced efficacy besides environmental pollution and food residues (Waller et al. 1995, Herd 1995). To decrease these negative impacts, the phytotherapy is an alternative tool that has been studied by many researches nowadays. The study of plants from Annonacea family has demonstrated the presence of active substances with parasiticidal effects (Duret et al. 1998). Annona squamosa seed powder is popularly used against insects in Northeast of Brazil (Braga 2001). In the search for new anthelmintic agents to be used in the control of

*Member Academia Brasileira de Ciências Correspondence to: Dra. Claudia Maria Leal Bevilaqua E-mail: claudiamlb@yahoo.com.br goat nematodes, the anthelmintic activity of extracts and isolated compounds of $A$. squamosa seeds were evaluated on egg hatching of $H$. contortus.

\section{MATERIALS AND METHODS}

PREPARATION OF A. squamosa EXTRACTS

The seeds of $A$. squamosa were obtained by manual extraction from fruits bought in the central market of Fortaleza. The extracts were prepared by the methodology performed by Nonfon (1990) as follows: A. squamosa seeds $(2 \mathrm{~kg})$ were triturated to a powder that was mixed with methanol/water solution (90:10, 31 ) and left in contact for seven days. This mixture was filtered and an aliquot of this initial solution $(300 \mathrm{ml})$ was evaporated to dryness for bioassay analysis. The aqueous-methanol solution was evaporated under reduced pressure using a rotatory evaporator. Methanol was eliminated and the remaining aqueous solution was transferred to a separatory funnel and washed up four times $(4 \times 30 \mathrm{ml})$ with ethyl acetate that was evaporated to obtain the correspondent extract $(15.0 \mathrm{~g})$. The aqueous layer was dried in a water bath to obtain the aqueous extract (44.0 g). 


\section{ISOLATION OF ACETOGENIN 1}

The Ethyl acetate extract (EtOAc) (15 g) was submitted to a silica gel (0.063-0.2 $\mathrm{mm})$ being eluted with chloroform, ethyl acetate and methanol in mixtures of increasing polarity. Fifty-two $(10 \mathrm{ml})$ fractions were obtained and compared by TLC using silica gel kieselgel 60 from Merck, visualized by exposure to $\mathrm{I}_{2}$ vapor. Compound $\mathbf{1}$ (302 mg) was isolated by elution the column with $100 \%$ ethyl acetate.

\section{Preparation of Acetyl Derivative (1a)}

The acetyl derivative was obtained by reaction of compound $1(100 \mathrm{mg})$ with acetic anhydride $(3 \mathrm{ml})$ and pyridine $(1 \mathrm{ml})$ mixture at room temperature for 24 hours. Then a hydrochloric acid solution (5\%) was added $(10 \mathrm{ml})$. The reactional mixture was transferred to a separatory funnel and extracted with chloroform $(3 \times 5 \mathrm{ml})$. The organic layer, containing the acetyl derivative was washed with water $(5 \times 5 \mathrm{ml})$, dried with sodium sulfate and the solvent was evaporated leaving 1 a $(80 \mathrm{mg})$ (Furniss et al. 1989).

\section{Chemical Analysis of Acetogenin 1}

Optical rotation was made in $\mathrm{CHCl}_{3}$ (Perkin Elmer 341); IR spectra were recorded on Perkin Elmer FTIR spectrum 100 spectrophotometer and the values are expressed in $\mathrm{cm}^{-1}$. NMR spectra were recorded on a Brucker Avance DRX-500 spectrometer in $\mathrm{CDCl}_{3}$. $70 \mathrm{eV}$ EI-Mass spectra was obtained using a HewlettPackard 5971 GC/MS instrument employing the following conditions: column: Dimethylpolysiloxane DB-1 coated fused silica capillary column $(30 \mathrm{~m} \times 0.25 \mathrm{~mm}$ $\times 0.25 \mathrm{~mm})$; carrier gas: $\mathrm{He}(1 \mathrm{ml} / \mathrm{min})$; capillary injector operating at $250^{\circ} \mathrm{C}$ in the split mode $(1: 100)$; detector temperature: $200^{\circ} \mathrm{C}$; column temperature: $35-180^{\circ} \mathrm{C}$ at $4^{\circ} \mathrm{C} / \mathrm{min}$ then $180-250^{\circ} \mathrm{C}$ at $10^{\circ} \mathrm{C} / \mathrm{min}$; mass spectra: electron impact. High-resolution mass spectra were obtained in an ultrOTOF $_{Q}$ - ESI-TOF Mass Spectrometer, Bruker Daltonics, Billerica, MA, USA. Experiment conditions: Infusion bomb, Flux $300 \mu \mathrm{l} / \mathrm{h}$, Mobile phase for solubilization: $\mathrm{H}_{2} \mathrm{O}: \mathrm{MeOH}(20: 80)$. Detection mode was positive and negative for the sample. For internal calibration it was used a $10 \mathrm{mg} / \mathrm{ml} \mathrm{NA}$-TFA solution and for external calibration a $10 \mathrm{mM}$ sodium formiate solution. Analysis conditions: End Plate: 4000 Volts, Capil- lary: 4500 Volts, Capillary Exit: 300 Volts, Skimmer 1: 50 Volts, Skimmer 2:25 Volts, Transfer: $90 \mu \mathrm{s}$, Collision Exit Gate: $80 \mu \mathrm{s}$. TLC analyses were performed on a 3$10 \mathrm{~cm}$ aluminum sheet precoated with silica gel 60-254 (Merck) (Solvent system: $\mathrm{CHCl}_{3} /$ EtOAc 3:7). $\mathrm{SiO}_{2}$, 200-400 mesh (Merck) was used for column chromatography.

Compound 1 was isolated as a viscous oil: $\{\alpha\}_{D}^{20}$ $+11.57^{\circ}\left(\mathrm{c}=0.001, \mathrm{CHCl}_{3}\right)$; $\mathrm{UV}\left(\lambda_{\max }, \mathrm{MeOH}, \mathrm{nm}\right): 225$ ( $\log \varepsilon$ 3.19); IR (KBr) v $v_{\max } 3418,2927,2855,1748$, 1652, 1463, 1319, 1118, 1068, 1028, 953, 877, 756, $666 \mathrm{~cm}^{-1}$; ${ }^{1} \mathrm{H}$ NMR $\left(\mathrm{CDCl}_{3}, 500 \mathrm{MHz}\right)$ and ${ }^{13} \mathrm{C}$ NMR $\left(\mathrm{CDCl}_{3}, 125 \mathrm{MHz}\right)$ are showed in Table I. EIMS $70 \mathrm{eV}$ $m / z$ : 481(3), 341 (5), 327 (7), 281 (45), 253 (12), 155 (5), 111 (8), 85 (32), 71 (57), 57 (72), 43 (43). A mass spectral fragmentation of compound $\mathbf{1}$ in the EI mass spectrum is shown in Figure 1.

Compound 1a was obtained as a waxy solid: $\{\alpha\}_{D}^{20}$ $+15.57^{\circ}\left(\mathrm{c}=0.001, \mathrm{CHCl}_{3}\right)$; $\mathrm{UV}\left(\lambda_{\max }, \mathrm{MeOH}, \mathrm{nm}\right): 225$ $\left(\log \varepsilon\right.$ 2.61); IR (KBr) v $v_{\max } 2928,2855,1748,1653$, $1465,1436,1317,1250,1120,1070,1026,950,876$, $759,668 \mathrm{~cm}^{-1} ;{ }^{1} \mathrm{H} \mathrm{NMR}\left(\mathrm{CDCl}_{3}, 500 \mathrm{MHz}\right)$ and ${ }^{13} \mathrm{C}$ $\mathrm{NMR}\left(\mathrm{CDCl}_{3}, 125 \mathrm{MHz}\right)$. EIMS $70 \mathrm{eV} \mathrm{m} / z$ : 481 (4), 341 (5), 281 (58), 253 (18), 155 (4), 141 (5), 137 (6), 125 (4), $111(8), 97(17) . \mathrm{C}_{37} \mathrm{H}_{66} \mathrm{O}_{7}: 622.480306(\mathrm{M}+)$, $623.924945(\mathrm{M}+\mathrm{H}), 645.906374(\mathrm{M}+\mathrm{Na})$.

\section{Anthelmintic BioAssay - in vitro EGG HATCH TEST}

H. contortus eggs were recovered according to Hubert and Kerboeuf (1984). Briefly, $10 \mathrm{~g}$ of feces were collected directly from the rectum of sheep experimentally infected with $H$. contortus mixed with tepid water and filtered through 590; 149; 101 and $30 \mu \mathrm{m}$ aperture sieves. The eggs retained on the $30 \mu \mathrm{m}$ sieve were collected.

The in vitro egg hatch test was carried out by the method of Coles et al. (1992). To perform this test, a volume of $500 \mu \mathrm{l}$, with $250 \mu \mathrm{l}$ of the eggs solution (about 120 eggs) and $250 \mu \mathrm{L}$ of extract solution were placed in $5 \mathrm{ml}$ tubes. The extract solutions for the bioassay were prepared using the concentrations of the extracts tested were $25 ; 5 ; 1 ; 0.2 ; 0.04 \mathrm{mg} \mathrm{ml}^{-1}$, the negative control was the diluent Tween 80 and the positive control thiabendazole $\left(0.1 \mu \mathrm{g} \mathrm{ml}^{-1}\right)$. After incubation for 48 hours, a drop of Lugol was added. All larvae and eggs 
TABLE I

${ }^{1} \mathrm{H}(500 \mathrm{MHz})$ and ${ }^{13} \mathrm{C}(100 \mathrm{MHz})$ NMR spectral data for 1 and 1a, including heteronuclear 2D shift-correlated obtained by ${ }^{1} \mathrm{H}$ and ${ }^{13} \mathrm{C}-\mathrm{COSY}-{ }^{n} J_{C H}(\mathbf{n}=1, \mathrm{HMQC}, \mathbf{n}=\mathbf{2}$ and 3 , HMBC) experiments, in $\mathrm{CDCl}_{3}$ as solvent, chemical shifts $(\delta, \mathbf{p p m})$ and coupling constants $\left(\mathrm{J}, \mathrm{Hz}\right.$, in parenthesis). ${ }^{a}$

\begin{tabular}{|c|c|c|c|c|c|c|}
\hline & \multicolumn{4}{|c|}{$1 \mathrm{a}$} & & \\
\hline & \multicolumn{2}{|c|}{${ }^{1} \mathrm{H}_{-}{ }^{13} \mathrm{C}_{-} \mathrm{COSY}-{ }^{1} \mathrm{~J}_{\mathrm{CH}}$} & \multicolumn{2}{|c|}{${ }^{1} \mathrm{H}_{-}{ }^{13} \mathrm{C}-\mathrm{COSY}-{ }^{n} \mathrm{~J}_{\mathrm{CH}}$} & \multicolumn{2}{|r|}{1} \\
\hline & $\delta_{C}$ & $\delta_{H}$ & ${ }^{2} \mathrm{~J}_{C H}$ & ${ }^{3} \mathrm{~J}_{\mathrm{CH}}$ & $\delta_{C}$ & $\delta_{H}$ \\
\hline \multicolumn{7}{|l|}{$\mathrm{C}$} \\
\hline 1 & 173.9 & - & & $2 \mathrm{H}-3 ; \mathrm{H}-35$ & 173.8 & - \\
\hline 2 & 134.2 & - & $2 \mathrm{H}-3 ; \mathrm{H}-35$ & & 134.2 & - \\
\hline $\mathrm{CH}_{3} \mathrm{C}=\mathrm{O}$ & $170.9 ; 170.8 ; 170.6$ & - & - & - & - & - \\
\hline \multicolumn{7}{|l|}{$\mathrm{CH}$} \\
\hline 5 & 74.0 & $4.91 \mathrm{~m}$ & & & 71.7 & $3.62 \mathrm{~m}$ \\
\hline 15 & 75.0 & $4.91 \mathrm{~m}$ & & & 74.1 & $3.43 \mathrm{~m}$ \\
\hline 16 & 80.0 & $4.04 \mathrm{~m}$ & & & $83.2^{a}$ & $3.84 \mathrm{~m}$ \\
\hline 19 & 81.2 & $3.93 \mathrm{~m}$ & & & $82.5^{a}$ & $3.94 \mathrm{~m}$ \\
\hline 20 & 81.6 & $3.93 \mathrm{~m}$ & & & $82.1^{a}$ & $3.94 \mathrm{~m}$ \\
\hline 23 & 80.3 & $4.04 \mathrm{~m}$ & & & $82.7^{a}$ & $3.84 \mathrm{~m}$ \\
\hline 24 & 75.2 & $4.91 \mathrm{~m}$ & & & 71.4 & $3.43 \mathrm{~m}$ \\
\hline 35 & 148.8 & $7.02 \mathrm{~s}$ & H-36 & $2 \mathrm{H}-3 ; 3 \mathrm{H}-37$ & 148.9 & $6.99 \mathrm{~s}$ \\
\hline 36 & 77.5 & $5.05 \mathrm{~m}$ & H-35; 3H-37 & & 77.4 & $5.02 \mathrm{~m}$ \\
\hline \multicolumn{7}{|l|}{$\mathrm{CH}_{2}$} \\
\hline 3 & 26.0 & $2.32(\mathrm{t}, 8.1)$ & & & 25.6 & $2.29(\mathrm{t}, 7.8)$ \\
\hline 4 & 33.9 & $1.55 \mathrm{~m}$ & & & 37.1 & $1.56 \mathrm{~m}$ \\
\hline 6 & 33.8 & $1.55 \mathrm{~m}$ & & & 37.3 & $1.56 \mathrm{~m}$ \\
\hline 7 & 25.1 & $1.25 \mathrm{~m}$ & & & 24.8 & $1.28 \mathrm{~m}$ \\
\hline $8-12$ & $29.5-29.1$ & $1.25 \mathrm{~m}$ & & & $28.9-29.6$ & $1.28 \mathrm{~m}$ \\
\hline 13 & 25.1 & $1.25 \mathrm{~m}$ & & & 25.1 & $1.28 \mathrm{~m}$ \\
\hline 14 & 30.8 & $1.60 \mathrm{~m}$ & & & 33.0 & $1.56 \mathrm{~m}$ \\
\hline 17 & 27.3 & $1.99 \mathrm{~m} ; 1.60 \mathrm{~m}$ & & & 27.3 & $1.98 \mathrm{~m} ; 1.65 \mathrm{~m}$ \\
\hline 18 & 28.0 & $1.98 \mathrm{~m} ; 1.65 \mathrm{~m}$ & & & 28.4 & $1.98 \mathrm{~m} ; 1.65 \mathrm{~m}$ \\
\hline 21 & 28.2 & $1.98 \mathrm{~m} ; 1.65 \mathrm{~m}$ & & & 28.4 & $1.98 \mathrm{~m} ; 1.65 \mathrm{~m}$ \\
\hline 22 & 27.3 & $1.98 \mathrm{~m} ; 1.65 \mathrm{~m}$ & & & 27.3 & $1.98 \mathrm{~m} ; 1.65 \mathrm{~m}$ \\
\hline 25 & 30.8 & $1.60 \mathrm{~m}$ & & & 32.3 & $1.56 \mathrm{~m}$ \\
\hline 26 & 25.2 & $1.25 \mathrm{~m}$ & & & 25.6 & $1.28 \mathrm{~m}$ \\
\hline $27-31$ & $29.5-29.1$ & $1.25 \mathrm{~m}$ & & & $28.9-29.6$ & $1.28 \mathrm{~m}$ \\
\hline 32 & 31.7 & $1.25 \mathrm{~m}$ & $3 \mathrm{H}-33$ & $3 \mathrm{H}-34$ & 31.8 & $1.28 \mathrm{~m}$ \\
\hline 33 & 22.5 & $1.25 \mathrm{~m}$ & $3 \mathrm{H}-34$ & & 22.5 & $1.28 \mathrm{~m}$ \\
\hline \multicolumn{7}{|l|}{$\mathrm{CH}_{3}$} \\
\hline 34 & 14.0 & $0.87(\mathrm{t}, 6.6)$ & & & 14.0 & $0.90(\mathrm{t}, 7.0)$ \\
\hline 37 & 19.1 & $1.39(\mathrm{~d}, 6.8)$ & & & 19.1 & $1.43(\mathrm{~d}, 6.7)$ \\
\hline $\mathbf{C H}_{3} \mathrm{C}=\mathrm{O}$ & $21.0,21.1,21.2$ & $2.08,2.05,2.03$ & & & & \\
\hline
\end{tabular}

${ }^{a}$ Number of hydrogens bound to carbon atoms deduced by comparative analysis of DEPT- ${ }^{13} \mathrm{C}$ NMR spectra. Chemical shifts and coupling constants $(\mathrm{J})$ obtained from $1 \mathrm{D}{ }^{1} \mathrm{H}$ NMR spectra. ${ }^{1} \mathrm{H}-{ }^{1} \mathrm{H}-\mathrm{COSY}$ spectrum was also used in these assignments. 


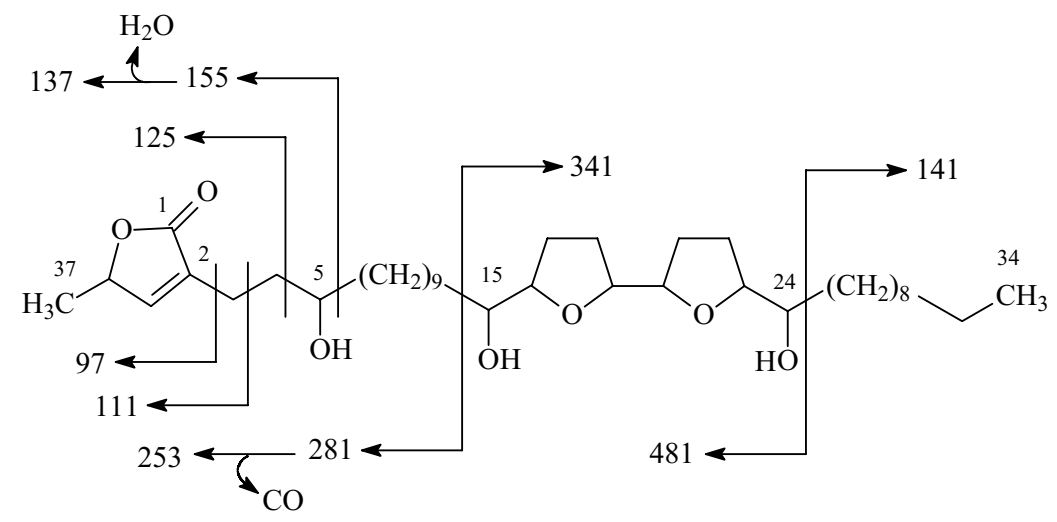

Fig. 1 - Mass spectral fragmentation of $\mathbf{1}$.

were counted using a microscope. Five replicates were performed for each concentration. Data were expressed as percentage of egg hatching inhibition. Statistical comparisons of the results from the egg hatching inhibition by the extracts on different concentrations were performed using Kruskal-Wallis test, with significance level of 5\%. The effective concentration to inhibit half eggs hatching $\left(\mathrm{CE}_{50}\right)$ for each extract was calculated by the equation which showed the tendency line with minimum determination coefficient of $70 \%$. The values of negative and positive controls are expressed as mean results.

\section{RESULTS AND DISCUSSION}

Table I displays the ${ }^{1} \mathrm{H}$ and ${ }^{13} \mathrm{C}$-COSY 2D NMR (HMQC and $\mathrm{HMBC}$ ) data of compound $\mathbf{1}$ and its acetyl derivative 1a. Compound 1 showed to be an acetogenin, a type of compound common in plants of Annonaceae family, with 37 carbons, three hydroxyl groups, an unsaturated lactone moiety $(\delta 6.99, \mathrm{H}-35 ; \delta 148.9, \mathrm{C}-35 ; \delta 134.2$, $\mathrm{C}-2 ; \delta 173.8, \mathrm{C}-1)$ and two adjacent tetrahydrofuran (THF) rings (Figure 2). The adjacent bis-THF rings with flanking $\mathrm{OH}$ groups in 1 were indicated by ${ }^{1} \mathrm{HNMR}$ resonances at $\delta 74.1$ (C-15), 83.2 (C-16), 82.5 (C-19), 82.1 (C-20), 82.7 (C-23) and 71.4 (C-24). The relative stereochemistry of the bis-THF moiety of $\mathbf{1}$ was suggested to be threo-trans-threo-trans-erythro by careful comparison of the ${ }^{1} \mathrm{H}$ and ${ }^{13} \mathrm{C}$ NMR signals of $\mathbf{1}$ with stereochemically defined bis-THF acetogenins (Araya et al. 2002, Alali et al. 1999, Zhou et al. 2000, Hopp et al. 1998). The presence of three hydroxyl groups in the molecule was evidenced by an absorption band in the
IR at $3418 \mathrm{~cm}^{-1}$ and three singlets at $\delta 2.08,2.05$, and 2.03 in the ${ }^{1} \mathrm{H}$ NMR spectra of the acetyl derivative 1a. The presence of two THF rings was suggested by signals in the ${ }^{1} \mathrm{H}$ NMR at $\delta 3.43$ (H-15), 3.84 (H-16, H-19, $\mathrm{H}-24)$ and 3.95 (H-20, H-23), which integrated constitutes 6 protons. A third hydroxyl group was evidenced by ${ }^{1} \mathrm{H}$ NMR signal at $\delta 3.62$ and a ${ }^{13} \mathrm{C}$ NMR signal at $\delta$ 71.7. Its position was predicted to be at $\mathrm{C}-5$ based on the EIMS fragments ions at $\mathrm{m} / \mathrm{z} 155,111,137,111$ and 97 (Figure 1) common in other C-5 hydroxylated acetogenins (Alali et al. 1999) and associated signals of ${ }^{1} \mathrm{H}-{ }^{1} \mathrm{H}$ COSY, HMQC and HMBC of the acetyl derivative 1a. In the bidimensional homonuclear ${ }^{1} \mathrm{H}_{-}{ }^{1} \mathrm{H}$ COSY spectrum of $1 \mathbf{a}$, the sequence of couplings between $\mathrm{H}-3$ ( $\mathrm{t}, \delta 2.32)$ and $\mathrm{H}-4(\mathrm{~m}, \delta 1.55)$ and $\mathrm{H}-4$ with $\mathrm{H}-5(\mathrm{~m}, \delta 4.91)$ assures the presence of a hydroxyl group at C-5. The IR spectra of compound 1 showed as main peaks at $3418 \mathrm{~cm}^{-1}$ for hydroxyl groups and at 1748 and $1652 \mathrm{~cm}^{-1}$ for the $\mathrm{C}=\mathrm{O}$ and the double bond of the lactone moiety respectively, that are compatible with data of similar acetogenins from seeds of A. squamosa (Rupprecht et al. 1990).

The percentage of egg hatching inhibition of $H$. contortus using $\mathrm{MeOH} / \mathrm{H}_{2} \mathrm{O}$, aqueous, EtOAc extracts and compound $\mathbf{1}$ is shown in Table II.

The highest inhibition of egg hatching was obtained with the EtOAc extract, in the concentrations of 5 and $25 \mathrm{mg} \mathrm{ml}^{-1}$, which did not demonstrate significant difference from thiabendazole, at $0.1 \mu \mathrm{g} \mathrm{ml}^{-1}$. The aqueous extract showed an inhibition percentage higher than the negative control, Tween 80 , at $25 \mathrm{mg} \mathrm{ml}^{-1}$, but at $5 \mathrm{mg} \mathrm{ml}^{-1}$ was not statistically different from the nega- 


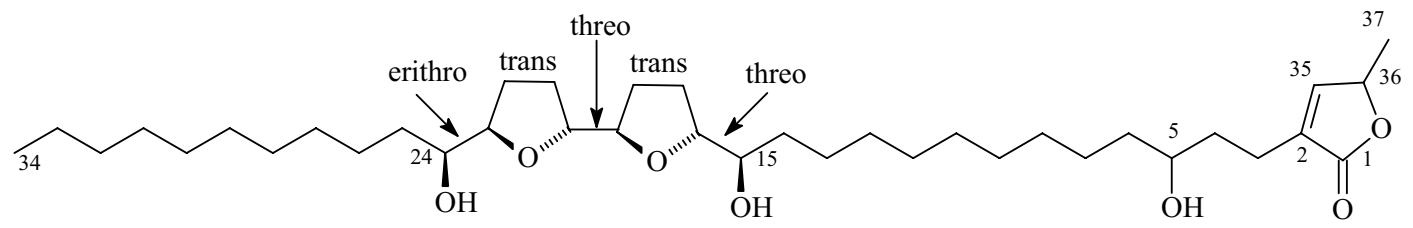

Fig. 2 - Structure of Acetogenin 1.

TABLE II

Inhibition percentage of Annona squamosa extracts and Compound 1 on Haemonchus contortus egg hatch test.

\begin{tabular}{c|c|c|c|c}
\hline \multirow{2}{*}{$\begin{array}{c}\text { Concentration } \\
\left(\mathrm{mg} \mathrm{mL}^{-1}\right)\end{array}$} & Ethyl acetate & Methanol/Water & Aqueous & Compound 1 \\
\cline { 2 - 5 } & $100.00^{A a b} \pm 0.0$ & $81.58^{B C b c} \pm 6.2$ & $52.64^{B C} \pm 10.9$ & $100.00^{A a} \pm 0.0$ \\
\hline 25 & $99.03^{A a b} \pm 0.4$ & $81.95^{A B a b} \pm 16.5$ & $14.28^{B c} \pm 4.2$ & $99.70^{A a} \pm 0.2$ \\
\hline 5 & $39.47^{B a b} \pm 13.7$ & $53.10^{C a} \pm 13.7$ & $13.74^{B C b} \pm 4.8$ & $51.60^{B a} \pm 7.5$ \\
\hline 1 & $8.97^{B C a} \pm 2.3$ & $4.81^{D a b} \pm 2.5$ & $3.02^{D b} \pm 2.5$ & $2.58^{C b} \pm 0.8$ \\
\hline 0.2 & $5.31^{C a} \pm 1.3$ & $2.80^{D a} \pm 1.5$ & $6.25^{C a} \pm 1.8$ & $3.33^{C a} \pm 1.1$ \\
\hline 0.04 & $4.25^{C} \pm 0.7$ & $4.25^{D} \pm 0.7$ & $4.25^{C D} \pm 0.7$ & $4.25^{C} \pm 0.7$ \\
\hline $\begin{array}{c}\text { Tween } 80(3 \%) \\
\left(0.1 \mu \mathrm{g} \mathrm{mL} \mathrm{mL}^{-1}\right)\end{array}$ & $100.00^{A} \pm 0.0$ & $100.00^{A} \pm 0.0$ & $100.00^{A} \pm 0.0$ & $100.00^{A} \pm 0.0$ \\
\hline
\end{tabular}

Capital letters compare means in the lines (different concentrations) and small letters in the columns (different extracts). Different letters indicate significantly different values $(\mathrm{P}<0.05)$.

tive control. The EtOAc extract was submitted to a silica gel column chromatography and the main isolated compound 1 was evaluated for its anthelmintic activity. Compound 1 inhibited the egg hatching more than $90 \%$ at 5 and $25 \mathrm{mg} \mathrm{ml}^{-1}$ concentrations, similarly to the EtOAc extract. The concentration that is effective for killing half of larvae amount $\left(\mathrm{CE}_{50}\right)$ of the aqueous, methanol/water, ethyl acetate extracts and compound $\mathbf{1}$ was $10.02,0.89,0.76$ and $0.78 \mathrm{mg} \mathrm{ml}^{-1}$ respectively.

The extracts $\mathrm{MeOH} / \mathrm{H}_{2} \mathrm{O}$, EtOAc and the acetogenin 1 at $5 \mathrm{mg} \mathrm{ml}^{-1}$ concentration had similar results in the inhibition of egg hatching of $H$. contortus. This result could be explained by the fact that the extracts $\mathrm{MeOH} / \mathrm{H}_{2} \mathrm{O}$ and EtOAc possess several chemical compounds, and many of them could display ovicidal action. The total action of the extracts is a sum of the activities of their constituents (Rates 2001). A. squamosa aqueous extract did not show relevant activity, similarly to the aqueous extract of $A$. senegalensis bark in the $H$. contortus egg hatch inhibition test (Alawa et al. 2003).
Probably these results are due to the low solubility of acetogenins in water.

The ovicidal effect obtained with ethyl acetate extract is lower than synthetic anthelmintics nevertheless it is important when compared with other plant extracts. Assis et al. (2003) reported 20\% inhibition of $\mathrm{H}$. contortus egg hatching with ethyl acetate extract of Spigelia anthelmia at $12.5 \mathrm{mg} \mathrm{m}^{-1}$ and the EtOAc extract of A. squamosa showed $99 \%$ egg hatch inhibition at $5 \mathrm{mg} \mathrm{ml}{ }^{-1}$. The effect of eight acetogenins, isolated from Uvaria hookeri and $U$. narum, against $H$. contortus adult specimens showed a negative relationship between the death time in minutes and acetogenins concentration (Padmaja et al. 1993). In conclusion, the seeds of $A$. squamosa represent an alternative natural source for anthelmintic compounds.

\section{ACKNOWLEDGMENTS}

This work received financial support from Conselho Nacional de Desenvolvimento Científico e Tecnológico 
(CNPq), Fundação Cearense de Apoio ao Desenvolvimento Científico e Tecnológico (FUNCAP) and Projeto de Apoio ao Desenvolvimento de Tecnologias Agropecuárias para o Brasil/ Empresa Brasileira de Pesquisa Agropeduária (PRODETAB / EMBRAPA) government agencies. Authors are grateful to Centro de Ressonância Magnética Nuclear do Nordeste (CENAUREN), Universidade Federal do Ceará (UFC) for the NMR spectral data and to Dr. Alberto J. Cavalheiro from Chemistry Institute, Universidade Estadual Paulista (UNESP) for high resolution mass spectra.

\section{RESUMO}

Extratos das sementes de Annona squamosa demonstraram atividade anti-helmíntica contra Haemonchus contortus, o principal nematódeo de ovinos e caprinos no Nordeste do Brasil. O composto 1 foi isolado do extrato acetato de etila e inibiu a eclosão dos ovos de $H$. contortus a $25 \mathrm{mg} \mathrm{ml}^{-1}$. A estrutura de 1 foi determinada como uma acetogenina $\mathrm{C}_{37}$ tri-hidroxi bistetrahydrofurano adjacente, baseando-se nos dados espectrais.

Palavras-chave: Haemonchus contortus, nematódeos, anonácea, fitoterapia.

\section{REFERENCES}

Alali FQ, LiU X and McLaughlin JL. 1999. Annonaceous Acetogenins: Recent Progress. J Nat Prod 62: 504 540 .

Alawa CBI, Adamu Am, Gefu Jo, Ajanusi OJ, AbDu PA, Chiezey NP, Alawa JN AND Bowman DD. 2003. In vitro screening of two Nigerian medicinal plants (Vernonia amygdalina and Annona senegalensis) for anthelmintic activity. Vet Parasitol 113: 73-81.

Araya H, Sahai M, Singh S, Singh AK, Yoshida M, HaRA N AND Fujimoto Y. 2002. Squamocin- $\mathrm{O}_{1}$ and squamocin- $\mathrm{O}_{2}$, new adjacent bis-tetrahydrofuran acetogenins from the seeds of Annona squamosa. Phytochemistry 61: 999-1004.

Arosemena NAE, Bevilaqua CML, Melo ACFL and GIRÃO MD. 1999. Seasonal veriations of gastrointestinal nematodes in sheep and goats from semi-arid area in Brazil. Rev Med Vet 150: 873-876.

Assis LM, Bevilaqua CML, Morais SM, Vieira LS, Costa CTC AND SouzA JAL. 2003. Ovicidal and larvicidal activity in vitro of Spigelia anthelmia Linn. extracts on Haemonchus contortus. Vet Parasitol 117: 43-49.
Braga R. 2001. Plantas do Nordeste - Especialmente do Ceará, Coleção Mossoroense, $5^{\mathrm{a}}$ ed., 204 p.

Coles GC, Bauer FHM, Borgsteede S, Greerts S, KLEI MA, TAYlor MA AND WALler PJ. 1992. World Association for the Advancement of Veterinary Parasitology (W.A.A.V.P.) methods for detection of anthelmintic resistance in nematodes of veterinary importance. Vet Parasitol 44: 35-44.

Duret P, Hocqmuller R and CaVe A. 1998. Bulladecin and Atemotetrolin, two bis-tetrahydrofuran acetogenins from Annona atemoya seeds. Phytochemistry 48: 499506.

FURNISS BS, HANNAFORD AJ, SMITH PWG AND TATChell AR. 1989. Vogel's Textbook of Pratical Organic Chemistry, Longman Scientific \& Technical, London, $1514 \mathrm{p}$.

HERD PR. 1995. Equine parasite control keeping up with evolution. Vet Med 90: 447-480.

Hopp DC, Alali FQ, Gu Z and MCLaughlin JL. 1998. Three new bioactive bis-adjacent THF-ring acetogenins from the bark of Annona squamosa. Bioorg Med Chem 6: $569-575$.

Hubert J AND Kerboeuf D. 1984. A new method for culture of larvae used in diagnosis of ruminant gastrointestinal strongilosis: comparation with fecal cultures. Can J Comp Med 48: 63-71.

Menezes RCAA, Vieira LS, Cavalcante ACR, CAVAda BS, Oliveira JTA AND Moreira RA. 1992. Estudos preliminares in vitro da atividade ovicida de folhas e sementes de quatro leguminosas sobre Haemonchus contortus de caprinos. Arquivos da UFRRJ, Brasil 15: $121-127$

Nonfon M. 1990. Annonis from Annona squamosa. Phytochemistry 29: 1951-1954.

Padmaja V, Thankamany V and Hisham A. 1993. Antibacterial, antifungal and anthelmintic activities of root barks of Uvaria hookeri and Uvaria narum. J Ethnopharmacol 40: 181-186.

Pinheiro RR, Gouveia AMG, Alves FSF AND HadDad JPA. 2000. Aspectos epidemiológicos na caprinocultura cearense. Arq Brasil Méd Vet Zoot 52: 534-543.

RATES SMK. 2001. Plants as source of drugs. Toxic 39: 603-613.

Rupprecht JK, Hui Y AND MCLaughlin JL. 1990. Annonaceous acetogenins: a Review. J Nat Prod 53: 237278. 
WALler PJ, DASH KM, BARger IA, LE JAMBRE LF AND

PlANT J. 1995. Anthelmintic resistance in nematode parasites of sheep: learning from the Australian experience. Vet Rec 136: 411-413.
Zhou GX, Chen RY, HANG YJ AND YU DQ. 2000. New Annonaceous acetogenins from the Roots of Uvaria calamistrata. J Nat Prod 63: 1201-1204. 